\title{
CLEC12A Gene
}

National Cancer Institute

\section{Source}

National Cancer Institute. CLEC12A Gene. NCI Thesaurus. Code C162376.

This gene is involved in carbohydrate binding, signal transduction and the negative regulation of macrophage/granulocyte functions. 